\title{
Виробничі випробування кращих сортів фундука (Corylus domestica Kos. et Opal.) колекції НАП «Софіївка» НАН України
}

\author{
Іван С. Косенко, Олександр А. Балабак \\ Наџіональний дендрологічний парк «Софіївка» НАН України, м. Умань, e-mail: ndp.sofievka@gmail.com; o.a.balabak@ukr.net \\ ORCID ID0000-0003-2085-7477; ORCID ID0000-0002-7435-9783
}

\section{Реферат.}

Meта. Вивчення врожайності сортів фундука (Corylus domestica Kos. et Opal.) колекџії НДП «Софіївка» НАН України і їі стабільності в умовах різних регіонів України було визначено метою досліджень. Матеріали i методи. Врожайність 165 сорто-зразків фундука і лішини досліджували у ланках колекџійного й гібридного саду та саду первинного сортовивчення НДП «Софї̈вка НАН України за загальновживаними методиками. П’ять краших сортів були включені у програму виробничих випробувань, шо проводились у семи господарствах різних регіонів України. Статистичнй аналіз отриманих даних проводили методом дисперсійного аналізу, використовуючи

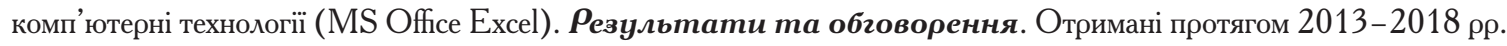
дані засвідчили, що в екологічних умовах України сорти фундука колекџї НДП «Софіївка», зокрема новий сорт Софіївський 15, можуть успішно вирошуватись у виробничих насадженнях. У більшості регіонів Софіївський 15 суттєво переважав контрольний сорт Дар Павленко за врожайністю, характеризуючись більшою стабільністю по роках і кулястою формою горіхів. Висновки. Створений в НДП «Софї̈вка новий сорт фундука Софї̈вський 15 підготовлено до подання до Українського інституту експертизи сортів рослин для державної науково-технічної експертизи з метою реєстраџії і поширення в садівниџтві України.

Ключові слова: врожайність сортів фундука, сад первинного сортовивчення, сорт Софіївський 15 , селекџія, агрокліматичні умови України.

\section{Cultivar Field Testing of the Best Hazelnut Cultivars (Corylus domestica Kos. et Opal.) of the National Dendrological Park "Sofiyivka" of the NAS of Ukraine Collection}

Ivan S. Kosenko, Oleksandr A. Balabak

National Dendrological Park «Sofiyivka» of NAS of Ukraine, Uman, Cherkassy region

e-mail: ndp.sofievka@gmail.com; o.a.balabak@ukr.net

ORCID ID0000-0003-2085-7477; ORCID ID0000-0002-7435-9783

\begin{abstract}
.
Aims. The aim of the article is to study the hazelnut cultivars yield (Corylus domestica Kos et Opal.) in the collection of the NDP "Sofiyivka" of NAS of Ukraine, and also its stability in conditions of different regions of Ukraine. Methods. The yields of the 165 hazelnut and filbert cultivars had been investigated in collective and hybrid garden and the garden of primary cultivar studying of NDP "Sofiyivka" of NAS of Ukraine on commonly used methods. Five best cultivars were included in the field testing programme. That testing had been conducted in the seven farms in different regions of Ukraine. Statistical inference of the received data had been made using the method of dispersive analyses by means of computer technologies (MS Office Excel). Results. The obtained during 2013-2018 data proved that the cultivars from the collection of NDP "Sofiyivka”, including the new Sofiyivskyi 15 cultivar, can be successfully grown in productive plantings of the agro-climatic conditions of Ukraine. Sofiyivsky 15 cultivar had better characteristics of yield stability and round shape of nuts, in comparison to the control Dar Pavlenko cultivar, in the most of the regions. Conclusions. New hazelnut Sofiyivskyi 15 cultivar was created on the base of the NDP "Sofiyivka" and provided for submission into
\end{abstract}


the Ukrainian Institute for Plant Variety Examination for scientific and technological evaluation in order to register and introduce in the Ukrainian horticulture.

Key words: yield of hazelnut cultivars, garden of primary cultivar studying, Sofiyivsky 15 cultivar, breeding, agro-climatic conditions of Ukraine.

Вступ/Introduction. Природні умови всіх агрокліматичних регіонів України (Kulbida et al., 2013) џілком задовільні шодо забезпечення потреб фундука у температурному режимі і тривалості фотоперіоду (Kosenko et al., 2008). Решта проблем вирощування фундука можуть бути розв' язані організаційно-агротехнічними заходами, шо робить досяжною перспективу економічно-доџільного виробниџтва його горіхів в Україні, а підвишення врожайності може бути досягнене методами селекџї (Molnar, 2011), про шо свідчать результати наших багаторічних досліджень (Kosenko et al., 2015, 2016, 2017a, b). На фоні досить стабільного шорічного зростання площі насаджень фундука у світі (Hazelnuts ..., 2017), що спостерігається впродовж останніх десятиріч, і яка у 2017 р. досягла понад 670 тис. га, показники валового виробниџтва його нелущених горіхів коливаються від 616 тис. тон у 2004 р. до 1 млн. 68 тис. тон у 2008 р. (рис. 1).

Світовим лідером виробниџтва горіхів фундука впродовж багатьох років була і залишається Туреччина, частка якої у џій кількості становить $70-75 \%$ зі џорічним виробниџтвом 450-800 тис. тонн. 3 показником 100-130 тис. тонн друге місџе стабільно посідає Італія, а США й Азербайджан поділяють третє й четверте місџя із шорічним виробниџтвом 20-35 тис. тонн. У Грузії збирають у середньому 25-30, в Китаї й Ірані по 18-25, а в Іспанії до - 12-17 тис. тонн на рік. Франџія в останні роки збільшила виробниџтво до 8-10 тис. тонн. Дефіџит пропозиџій шодо горіхоплідних лише у країнах Західної Європи перевищує 100 тисяч тонн. Великі партій горіхів закуповують Італія, $\mathrm{Hi}$ меччина, Франџія, Росія, Швейџарія, Бельгія, Канада, Польща Нідерланди й Австрія, а також країни Скандинавії. На відміну від інших імпортерів Бельгія переважну кількість закуплених горіхів переробляє і різні кондитерські вироби продає у треті країни. 3 такою ж метою велику кількість лущених горіхів закуповує італійська транснаџіональна корпораџія Ферреро, шо спеџіалізується на кондитерських виробах і має фабрики та представниџтва у Німеччині, Франџї, Бельгї, Нідерландах, Швейџаріі, США, Британії та інших країнах світу, де виробляють горіхово-шоколадний крем-пасту Нутеллу, џукерки, шоколад тошо (Ciemniewska-Żytkiewicz et al., 2015).

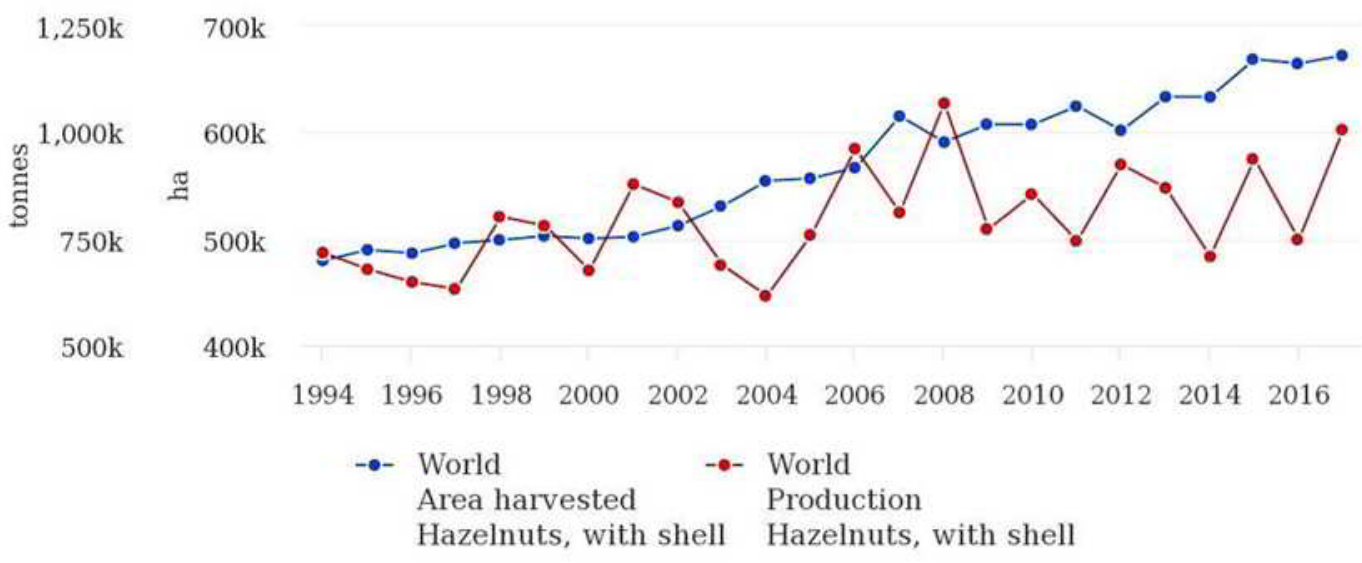

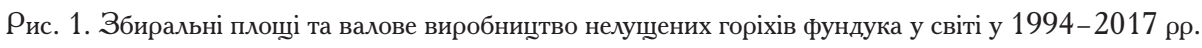
(за даними ФФАО; Hazelnuts ..., 2017)

Figure 1. The total world hazelnuts (with shell) area harvested \& production in 1994-2017

(according to FAOSTAT; Hazelnuts ..., 2017) 
У списку виробників горіхів фундука Україна посідає 30 місце в світі з показником лише 10-20 тонн, тоді як у 1995-98 рр. џя кількість була у п>ять-сім разів більшою (Hazelnuts ..., 2017). При џьому різке зменшення збиральних плош, шо почалося у 1999 р., досягло свого мінімуму у 2006 р., після чого почалося повільне зростання плош під фундуком при нестабільному виробниџтві його горіхів (рис. 2).

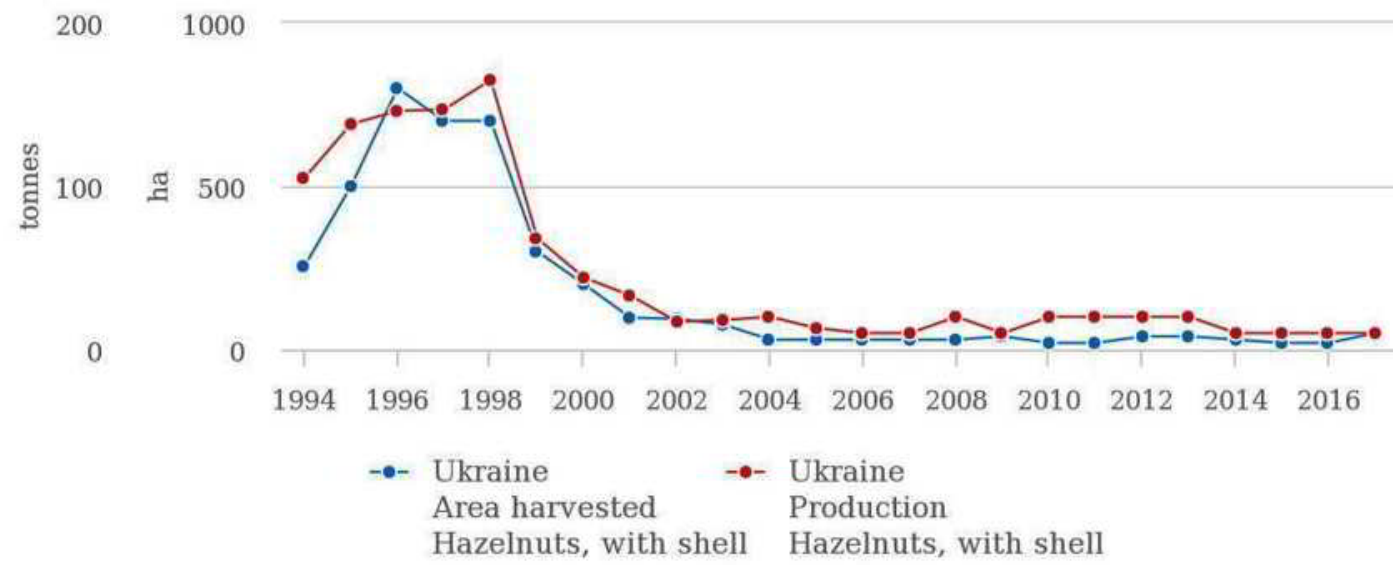

Рис. 2. Збиральні плоші та валове виробниџтво нелушених горіхів фундука в Україні у 1994-2017 рр. (за даними СDAO; Hazelnuts ..., 2017)

Figure 2. The hazelnuts (with shell) area harvested \& production by Ukraine in 1994-2017 (according to FAOSTAT; Hazelnuts ..., 2017)

На підставі аналізу динаміки загальної культури харчування i, відповідно, перспективи наближення середньорічного споживання плодів горіхів до 3,6 кг на одну особу в рік можна прогнозувати шорічне зростання внутрішнього попиту у обсягах $2-3 \%$, унаслідок чого середньорічний попит складатиме у 2021 -2025 - понад 12 тис. тонн горіхів фундука. Вітчизняне виробниџтво разом із імпортованими горіхами наразі не забезпечує навіть 25-30\% џієі потреби (Satina et al., 2011). Џе зумовлює потребу розвитку фундукарства і необхідність удосконалення сортименту, насамперед його поповнення вітчизняними сортами.

Матеріали і методи/Materials and Methodology. Досліджували врожайність 165 сорто-зразків фундука і ліщини, зокрема створених в НДП «Софіївка» НАН України, а також отриманих з інших наукових установ України і світу у ланках колекџійного й гібридного саду та саду первинного сортовивчення. Відібрані за комплексом господарсько-џінних ознак у колекџійному саду сорти були включені у випробування в саду первинного сортовивчення. П'ять краших сортів, шо за господарськоцінними ознаками істотно перевищували груповий стандарт у ланках первинного сортовивчення, були включені у програму виробничих випробувань, що проводились у семи господарствах з різних областей України. Зокрема у фермерському господарстві Ганієва Нарімана (с. Ескі-Сарай, Сімферопольського $\rho$-ну, АО Крим); фермерському господарстві Володимира Ісаака (м. Ужгород, Закарпатської обл.); Дослідно-селекційному дендрологічному лісовому џентрі «Веселі Боковеньки» (с. Веселі Боковеньки, Долинського р-ну, Кіровоградської обл.); фермерському господарстві Миколи Громлюка «Трояндова республіка» (с. Кірове, Комінтернів-

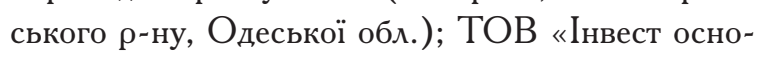

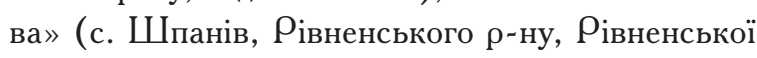
обл.); розсаднику фундука Анатолія Космидайла (с. Велика Севастьянівка, Христинівського $\rho$-ну, Черкаської обл.) та Державному дендрологічному парку «Тростянеџь» НАН України (с. Тростянеџь, Ічнянського $\rho$-ну, Чернігівської обл.). За контрольний сорт в усіх виробничих дослідах було використано вітчизняний сорт Дар Павленка.

Закладання станџійних і виробничих дослідів проводили згідно з Програмою і методикою сортовивчення плодових, ягідних і горіхоплідних культур (Sedov, \& Ogoltsova, 1999) та Методикою державної науково-технічної (кваліфікаџійної) експертизи 
сільськогосподарських видів рослин на придатність до поширення в Україні (Kienko et al., 2015) з деякими уточненнями відповідно до спеџифіки культури (Biganova et al., 2016; Kosenko et al., 2017 b; Sukhorukikh et al., 2018). Статистичний аналіз отриманих даних виконували методом дисперсійного аналізу (Fisher, 2006) у викладі сучасних фахівців з методики дослідної вправи у біологічних та агрономічних дослідженнях (Atramentova \& Utievska, 2007; Eshchenko et al., 2014), використовуючи комп'ютерні технології (MS Office Excel).

Результати та обговорення/Results and Discussion. Врожайність горіхів фундука у ланках колекційного й гібридного саду та саду первинного сортовивчення. змінювалась залежно від сорту та тривалості росту й розвитку його рослин. (табл. 1).

Таблиџя 1. Врожайність горіхів сортів фундука у колекџійному саду протягом перших трьох років після вступу у пору плодоношення, кг/га

Table 1. Nut yield of hazelnut cultivars in collective garden during the first three fruiting years, $\mathrm{kg} / \mathrm{ha}$

\begin{tabular}{|c|c|c|c|c|}
\hline \multirow{2}{*}{ Сорт/Cultivar } & \multicolumn{3}{|c|}{$\rho_{\text {iк урожаю/Fruiting year }}$} & \multirow{2}{*}{ Середнє/Average } \\
\hline & 2012 & 2013 & 2014 & \\
\hline $\begin{array}{l}\text { Урожайний-80 } \\
\text { UrozhaInil-80 }\end{array}$ & 5,6 & 100,8 & 271,6 & 126,0 \\
\hline $\begin{array}{l}\text { Грандіозниё } \\
\text { Grandioznil }\end{array}$ & 7,8 & 117,6 & 257,6 & 127,7 \\
\hline $\begin{array}{l}\text { Корончатий } \\
\text { Koronchatil }\end{array}$ & 5,6 & 86,8 & 462,0 & 184,8 \\
\hline $\begin{array}{l}\text { Караманівський } \\
\text { Karamanivs'kiI }\end{array}$ & 53,2 & 176,4 & 355,6 & 195,1 \\
\hline $\begin{array}{l}\text { Морозівський } \\
\text { Morozivs'kil }\end{array}$ & 19,6 & 117,6 & 467,6 & 201,6 \\
\hline $\begin{array}{l}\text { Лозівський урожайний } \\
\text { Lozivs'kiI urozhaIniI }\end{array}$ & 16,8 & 98,0 & 518,0 & 210,9 \\
\hline $\begin{array}{l}\text { Болградська новинка } \\
\text { Bolgrads'ka novinka }\end{array}$ & 61,6 & 229,6 & 394,8 & 228,7 \\
\hline $\begin{array}{l}\text { Дар Павленка } \\
\text { Dar Pavlenka }\end{array}$ & 95,2 & 226,8 & 380,8 & 234,3 \\
\hline $\begin{array}{l}\text { Шедевр } \\
\text { Shedevr }\end{array}$ & 86,8 & 263,2 & 459,2 & 269,7 \\
\hline $\begin{array}{l}\text { Степовий } \\
\text { StepoviI }\end{array}$ & 86,8 & 266,0 & 470,4 & 274,4 \\
\hline $\begin{array}{l}\text { Зоринський } \\
\text { Zorins'kil }\end{array}$ & 64,4 & 254,8 & 509,6 & 276,3 \\
\hline $\begin{array}{l}\text { Фундук-85 } \\
\text { Funduk-85 }\end{array}$ & 140,0 & 338,8 & 456,4 & 311,7 \\
\hline $\begin{array}{l}\text { Зюйдівський } \\
\text { Dokhidnil }\end{array}$ & 114,8 & 392,0 & 638,4 & 381,7 \\
\hline $\begin{array}{l}\text { Дохідний } \\
\text { DokhidniI }\end{array}$ & 179,2 & 355,6 & 809,2 & 448,0 \\
\hline $\begin{array}{l}\mathrm{HIP}_{05} \\
\mathrm{LSD}_{05}\end{array}$ & 3,6 & 11,6 & 24,8 & \\
\hline
\end{tabular}

Найбільшу врожайність горіхів фундука у колекџійному саду в середньому за три роки досліджень
(2012-2014 рр.) формували рослини сорту Дохідний з показником 448,0 кг/га, а значно нижчою 
врожайність була у рослин сортів Урожайний-80 $(126,0$ кг/га) і Грандіозний $(127,7$ кг/га). Рослини решти вивчених сортів фундука характеризувались середньою врожайністю від 184,8 кг/га до 381,7 кг/га. У роки досліджень урожайність горіхів фундука більше змінювалась залежно від сортових особливостей входження в стабільне плодоношення, ніж від погодних умов вегетаџійного періоду. Так, сорти Караманівський, Болградська новинка, Дар Павленка, Шедевр, Степовий, Зоринський, ФУндук-85, Зюйдівський і Дохідний, шо характеризувалися більш раннім початком плодоношення, показали значний ріст врожайності, зокрема з 53,2-179, 2 кг/га до 355,6-809,2 кг/га або в 1,7-4,5 рази. Решта вивчених сортів вступали в товарне плодоношення пізніше, іх врожайність у 2012 р. (перший рік оцінювання) становила лише 5,6-19,6 кг/га, що в 9,1-32,0 рази менше порівняно з крашим за врожайністю сортом Дохідний.

У ланках гібридного саду, де вивчалося насінне потомство від контрольованих схрешувань, а також від вільного запилення краших сортів і сорто-форм колекційного саду спостерігали широкий спектр генотипів за господарсько-корисними ознаками. 3 популяџій сіянџів від схрешування найбільш продуктивних в умовах України вітчизняних та інтродукованих сортів з представниками C. chinensis Franch. та C. avellana 'Fuscorubra' було виділено найбільш перспективні форми для безпосереднього сортовивчення і включено іх у станџійні випробування в саду первинного сортовивчення НДП «Софіївка» НАН України (Kosenko et al., 2015) разом із крашими сортами фундука відібраними у колекџійному саду. Саме з џих матеріалів було створено ряд нових сортів, зокрема Софіївський 1 (Україна-50 × C. avellana 'Fuscorubra'), Софіївський 2 (Дар Павленка $\times$ C. avellana 'Fuscorubra'), Софї̈вський 3 (Черкеський- $2 \times$ C. chinensis) та Сoфіївський 15 (Гарібальді $\times$ С. chinensis). На џьому етапі найбільш перспективним для впровадження у вітчизняне фундукарство виявився сорт Софіївський 15 , шо вступив у плодоношення на третій рік після схрешування. Хоча у перший рік плодоношення сіянеџь сформував лише жіночі квітки, џе не завадило зробити органолептичну оџінку плодів, шо розвинулись від перехресного вільного запилення пилком від оточуючих рослин фундука і лішини.

Зазначені нові сорти характеризуються кулястими або майже кулястими (Софіївський 3 ,
Софіївський 15) плодами, підвищеною в порівнянні з туреџькими і азербайджанськими сортами зимостійкістю і посухостійкістю, а також відсутністю періодичності плодоношення. Окрім того, у складі жирних кислот в ядрах горіхів сортів Софіївський 2 и Софіївський 4 домінували ненасичені жирні кислоти, шо дає підстави вважати їх перспективними для промислового вирошування сировини для отримання високоякісної фундукової олії та надзвичайно џінних для вітчизняної фармаџії ессенџіальних фосфоліпідів. Подібний профіль жирнокислотного складу олії був у сорту Софіївський 15 , тож, зважаючи на його високу продуктивність і скороплідність, а також зручну для переробки кулясту форму плоду (рис. 3) џей сорт видається найбільш перспективним.

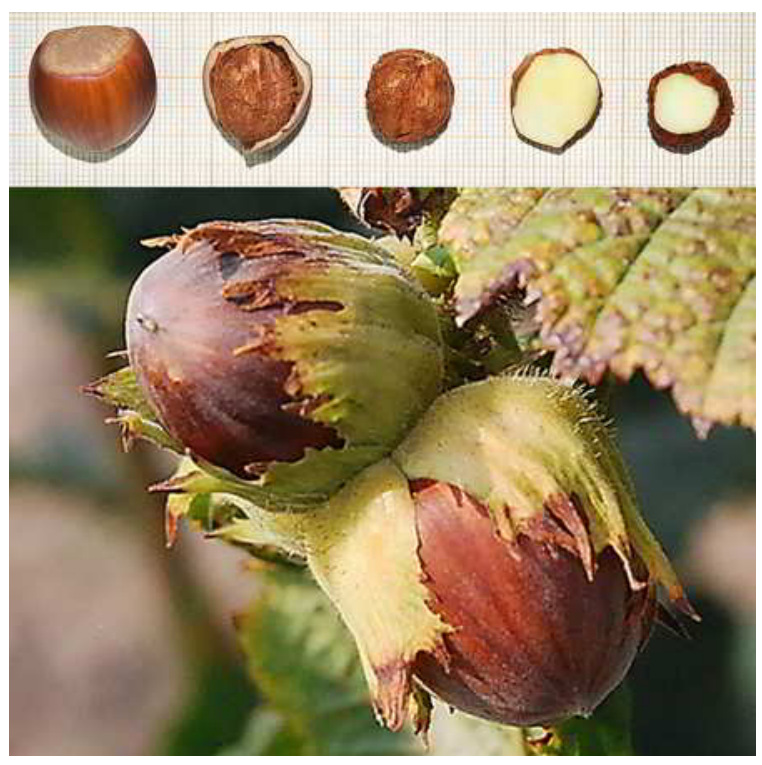

Рис. 3. Плоди нового сорту фундука Софіївський 15 Figure. 3. Fruits of new 'Sofiyivsky 15' hazelnut cultivar

У станџійних випробуваннях у саду первинного сортовивчення НДП «Софіївка» НАН України згадані нові сорти підтвердили свої переваги за комплексом господарсько-џінних ознак впродовж 2013-2018 рр., характеризуючись при џьому стрімким нароџуванням врожайності (табл. 2).

У середньому за 2013-2018 рр. крашими за врожайністю були виділені з колекџії сорти Дохідний, Зоринський, Зюйдівський, Морозівський, Степовий, Фундук-85 і Шедевр, які (за винятком виведеного у Всеросійському НДІ квітникарства і субтропічних культур сорту Зоринський) створені видатним українським селекџіонером 
Ф. А. Павленком в Українському науково-дослідному інституті лісівниџтва та агролісомеліораџї ім. Г.М. Висоџького, а також нові сорти нашої селекџї Софіївський 1 і Софіївський 15, з рівнем урожайності 1,33-1,56 т/га. Однак серед названих сортів найшвидше нарошували врожайність рослини сорту Морозівський - у 12,1 разів, тоді як сорти
Зоринський, Степовий і Шедевр - в 5,3-5,4 рази, Дохідний, Зюйдівський і Фундук-85 - у 3,7-4,5 рази, нові сорти Софї̈вський 1 і Софіївський 15 у 5,5 і 5,3 рази, а Софіївський 2 і Софіївський 3 у 6,7 і 9,5 разів відповідно. Џе свідчить про перспективи використання нових сортів у виробниџтві, а також залучення їх у подальшу селекџію.

Таблиџя 2. Врожайність горіхів сортів фундука в саду первинного сортовивчення, т/га

Table 2. Nut yield of hazelnut cultivars in the garden of primary cultivar studying, MT/ha

\begin{tabular}{|c|c|c|c|c|c|c|c|}
\hline \multirow{2}{*}{ Сорт/Cultivar } & \multicolumn{6}{|c|}{$\rho_{\text {ік урожаю/Fruiting year }}$} & \multirow{2}{*}{$\begin{array}{l}\text { Середне } \\
\text { Average }\end{array}$} \\
\hline & 2013 & 2014 & 2015 & 2016 & 2017 & 2018 & \\
\hline $\begin{array}{l}\text { Урожайний-80 } \\
\text { UrozhaIniI-80 }\end{array}$ & 0,18 & 0,27 & 0,51 & 0,96 & 1,43 & 1,69 & 0,84 \\
\hline $\begin{array}{l}\text { Грандіозний } \\
\text { Grandioznil }\end{array}$ & 0,11 & 0,25 & 0,39 & 0,91 & 1,34 & 1,59 & 0,76 \\
\hline $\begin{array}{l}\text { Корончатий } \\
\text { KoronchatiI }\end{array}$ & 0,08 & 0,46 & 0,87 & 1,42 & 2,29 & 2,42 & 1,25 \\
\hline $\begin{array}{l}\text { Караманівський } \\
\text { Karamanivs'kil }\end{array}$ & 0,17 & 0,35 & 0,68 & 1,19 & 1,66 & 1,84 & 0,98 \\
\hline $\begin{array}{l}\text { Морозівський } \\
\text { Morozivs'kiI }\end{array}$ & 0,11 & 0,46 & 0,90 & 1,53 & 2,41 & 2,58 & 1,33 \\
\hline $\begin{array}{l}\text { Лозівський урожайний } \\
\text { Lozivs'kiI urozhaIniI }\end{array}$ & 0,09 & 0,51 & 0,85 & 1,34 & 2,13 & 2,33 & 1,20 \\
\hline $\begin{array}{l}\text { Болградська новинка } \\
\text { Bolgrads'ka novinka }\end{array}$ & 0,22 & 0,39 & 0,75 & 1,22 & 1,78 & 2,03 & 1,06 \\
\hline $\begin{array}{l}\text { Дар Павленка } \\
\text { Dar Pavlenka }\end{array}$ & 0,22 & 0,38 & 0,72 & 1,24 & 1,79 & 2,08 & 1,07 \\
\hline $\begin{array}{l}\text { Шедев } \\
\text { Shedevr }\end{array}$ & 0,26 & 0,45 & 1,03 & 1,65 & 2,41 & 2,56 & 1,39 \\
\hline $\begin{array}{l}\text { Степовий } \\
\text { StepoviI }\end{array}$ & 0,26 & 0,47 & 0,99 & 1,54 & 2,43 & 2,59 & 1,38 \\
\hline $\begin{array}{l}\text { Зоринський } \\
\text { Zorins'kiI }\end{array}$ & 0,25 & 0,51 & 0,98 & 1,59 & 2,35 & 2,42 & 1,34 \\
\hline $\begin{array}{l}\text { Фундук-85 } \\
\text { Funduk-85 }\end{array}$ & 0,33 & 0,45 & 0,98 & 1,57 & 2,34 & 2,49 & 1,36 \\
\hline $\begin{array}{l}\text { Зюйдівський } \\
\text { Ziuldivs'kil }\end{array}$ & 0,39 & 0,63 & 1,04 & 1,71 & 2,42 & 2,57 & 1,46 \\
\hline $\begin{array}{l}\text { Дохідний } \\
\text { DokhidniI }\end{array}$ & 0,35 & 0,81 & 1,25 & 1,81 & 2,53 & 2,61 & 1,56 \\
\hline $\begin{array}{l}\text { Софіївський } 1 \\
\text { Sofiyivsky } 1\end{array}$ & 0,25 & 0,47 & 0,97 & 1,58 & 2,44 & 2,58 & 1,38 \\
\hline $\begin{array}{l}\text { Софіївський } 2 \\
\text { Sofiyivsky } 2\end{array}$ & 0,18 & 0,46 & 0,91 & 1,42 & 2,11 & 2,23 & 1,21 \\
\hline $\begin{array}{l}\text { Софіївський } 3 \\
\text { Sofiyivsky } 3\end{array}$ & 0,12 & 0,35 & 0,87 & 1,21 & 2,09 & 2,21 & 1,14 \\
\hline
\end{tabular}




\begin{tabular}{|l|c|c|c|c|c|c|c|}
\hline \multicolumn{1}{|c|}{1} & 2 & 3 & 4 & 5 & 6 & 7 & 8 \\
\hline $\begin{array}{l}\text { Софї̈вський } 15 \\
\text { Sofiyivsky } 15\end{array}$ & 0,27 & 0,46 & 1,09 & 1,68 & 2,53 & 2,61 & 1,44 \\
\hline $\begin{array}{l}\mathrm{HIP}_{05} \\
\text { LSD }_{05}\end{array}$ & 0,01 & 0,01 & 0,03 & 0,06 & 0,09 & 0,10 & \\
\hline
\end{tabular}

Для підготовлення до подання заявки на проведення кваліфікашійної експертизи на придатність до поширення в Україні найбільш перспективний за комплексом господарсько-дінних ознак, що включали високу продуктивність, скороплідність, зручну для кондитерської промисловості кулясту форму плоду та сприятливий для фармадії профіль жирнокислотного складу олії, сорт Софіївський 15 було включено в схему широких еколого-географічних виробничих досліджень разом з кількома відомими сортами, зокрема вітчизняними Дар Павленка і Шедевр, а також місџевим грузинським сортом Футкурамі та адигейським сорт народної селекџї̈ Черкеський-2 (виділеним у Північно-Кавказькому федеральному науковому џентрі садівниџтва, виноградарства, виноробства).

В усіх садах виробничого сортовивчення новий сорт Софіївський 15 перевищував за врожайністю контрольний сорт Дар Павленка з близькими показниками до сорту Шедевр у більшості господарств. Џе свідчить про високу екологічну стабільність сорту Софіївський 15 , який продемонстрував свої переваги у різних за грунтово-кліматичними умовами регіонах України у досить різні за метеорологічними показниками роки. Інтродуковані з кавказького регіону сорти Футкурамі та Черкеський-2 поступились за середньою врожайністю горіхів і контрольному сорту Дар Павленка, і решті вітчизняним сортам Софіївський 15 і Шедевр у Дослідно-селекційному дендрологічному лісовому центрі «Веселі Боковеньки» (с. Веселі Боковеньки, Долинського $\rho$-ну, Кіровоградської обл.); фермерському господарстві Миколи Громлюка «Трояндова республіка» (с. Кірове, Комінтернівського $\rho$-ну, Одеської обл.); ТОВ «Інвест основа» (с. Шпанів,

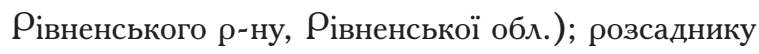
фундука Анатолія Космидайла (с. Велика Севастьянівка, Христинівського $\rho$-ну, Черкаської обл.) та Державному дендрологічному парку «Тростянеџь» НАН України (с. Тростянеџь, Ічнянського $\rho$-ну, Чернігівської обл.). При џьому у фермерському господарстві Ганієва Нарімана (с. Ескі-Сарай, Сімферопольського $\rho$-ну, АР Крим) та фермерському господарстві Володимира Ісаака (м. Ужгород, Закарпатської обл.) урожайність сортів Футкурамі та Черкеський-2 була близькою у Закарпатській обл. і дешо вишою в Криму, ніж урожайність контрольного сорту Дар Павленка, однак нижчою в обох пунктах випробування, ніж показники сортів Софї̈вський 15 і Шедевр (табл. 3).

Таблиџя 3. Врожайність горіхів сортів фундука у виробничому сортовивченні (2013-2018 рр.)* т/га Table 3. Nut yield of hazelnut cultivars in the garden of field testing $(2013-2018) *$, MT/ha

\begin{tabular}{|c|c|c|c|c|c|}
\hline \multirow[b]{2}{*}{ Місце випробування/Test Sites** } & \multicolumn{5}{|c|}{ Сорт/Cultivar } \\
\hline & 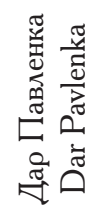 & 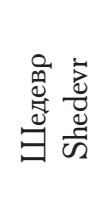 & 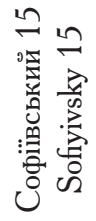 & 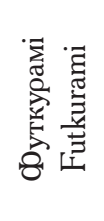 & 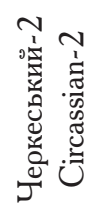 \\
\hline $\begin{array}{l}\text { с. Ескі-Сарай, } \mathrm{A} \rho \text { Крим } \\
\text { Eski-Saray village, } \mathrm{AR} \text { of Crimea }\end{array}$ & 1,04 & 1,37 & 1,42 & 1,12 & 1,14 \\
\hline $\begin{array}{l}\text { м. Ужгород, Закарпатської обл. } \\
\text { Uzhgorod city, Transcarpathian region }\end{array}$ & 1,05 & 1,29 & 1,25 & 1,01 & 1,03 \\
\hline $\begin{array}{l}\text { с. Веселі Боковеньки, Кіровоградської обл. } \\
\text { Vesely Bokovenki village, Kirovograd region }\end{array}$ & 0,95 & 1,15 & 1,19 & 0,59 & 0,61 \\
\hline
\end{tabular}




\begin{tabular}{|l|c|c|c|c|c|}
\hline \multicolumn{1}{|c|}{1} & 2 & 3 & 4 & 5 & 6 \\
\hline $\begin{array}{l}\text { с. Кірове Одеської обл. } \\
\text { Kirove village, Одеssa region }\end{array}$ & 1,05 & 1,29 & 1,22 & 0,81 & 0,85 \\
\hline $\begin{array}{l}\text { с. Шпанів, Рівненської обл. } \\
\text { Shpaniv village, Rivne region }\end{array}$ & 0,97 & 1,19 & 1,28 & 0,63 & 0,56 \\
\hline $\begin{array}{l}\text { с. Велика Севастьянівка, Черкаської обл. } \\
\text { Velika Sеvastyanivka village, Сherkasy region }\end{array}$ & 1,03 & 1,35 & 1,37 & 0,72 & 0,58 \\
\hline $\begin{array}{l}\text { с. Тростянеџь, Чернігівської обл. } \\
\text { Trostyanets urban village, Chernigov region }\end{array}$ & 0,62 & 0,85 & 0,92 & 0,51 & 0,47 \\
\hline
\end{tabular}

Примітка: * - 2010 рік садіння; ** - перелік господарств у розділі «Матеріали і методи»

Note: * - planting year is $2010 ; * *$ - List of test gardens in «Methods» section

Порівняння отриманих результатів з особливостями ґрунтово-кліматичних умов місџь розташування господарств, в яких були вивчені вищезгадані сорти, дає підстави пояснювати вагому перевагу вітчизняних сортів у більшості регіонів проведення досліджень їх крашою адаптованістю до більш суворих, порівняно з умовами кавказького регіону, з якого походять сорти СУукурамі та Черкеський-2. Менша різниџя в урожайності у господарствах АР Крим та Закарпатської області, очевидно зумовлена м'якшим кліматом џих регіонів з подібними до умов кавказького регіону характеристиками.

Висновки/Conclusions. Внаслідок вивчення колекції вітчизняних і інтродукованих сорто-зразків фундука і лішини з'ясувалося, шо вітчизняні сорти спроможні формувати більш високі врожаї в умовах більшості регіонів України. Створений в НДП «Софіївка новий сорт фундука Софіївський 15 , шо характеризується кулястими плодами, підвищеною зимостійкістю і посухостійкістю, відсутністю періодичності плодоношення, а також високою якістю жирнокислотного складу олії у поєднанні з високою продуктивністю і скороплідністю, підготовлено до подання до Українського інституту експертизи сортів рослин для державної науково-технічної експертизи з метою реєстрації і поширення в Україні.

Подяки/Acknowledgement. Матеріали статті частково грунтуються на результатах, отриманих у процесі виконання цільової програми наукових досліджень Відділення загальної біології НАН України «Основи функціонування та адаптації біологічних систем за умов дії біотичних і абіотичних факторів», завдання «Створення високопродуктивних сортів нового покоління сільськогосподарських культур із високим адаптивним потенціалом до несприятливих умов довкіляя» по темі «Теоретичні основи регенераџійних проџесів у представників моноеџійних і гермафродитних деревних рослин in vivo та in vitro» (номер державної реєстраџії 0112U002032. Автори висловлюють вдячність провідному науковому співробітникові НДП «Софї̈вка» НАН України канд. с.-г. наук, професору А.І. Опалку за слушні зауваження і џінні поради шодо підготовлення рукопису до друку.

\section{Список посилань/References}

Atramentova, L. O., \& Utievska, O. M. (2007). Biometriia: pidruchnyk. Kharkiv: Ranok. 176 s. (in Ukrainian).

Biganova S. G., Sukhorukikh Yu. I., Pchikhachev E. K., \& Fomicheva E. O. (2016). Some program and methodological aspects of the selection of filbert (hazelnut) in the Western Caucasus. New technologies. Vol. 4. P. 103-109.

Ciemniewska-Żytkiewicz H., Verardo V., Pasini F., Bryś J., Koczoń P., \& Caboni M. F. (2015). Determination of lipid and phenolic fraction in two hazelnut (Corylus avellana L.) cultivars grown in Poland. Food chemistry. Vol. 168. P. 615-622.

Eshchenko V. O., Kopitko P. G., Kostogriz P.V., \& Oprishko V.P. (2014). Osnovi naukovikh doslidzhen'v agronomiï: pidruchnik. Vinnicia: Edel'veIs i K. 332 s. (in Ukrainian).

Hazelnuts, with shell (2017). FAOSTAT Domains Production/Crops: Average. URL: http:/ /www. fao. org/ faostat/en/\#data/QC/visualize (Accessed 29 August 2018).

Kienko Z. B., Matus V.M. \& Pavliuk N.V. (compilers). (2015). Methods of doing the cultivar expertise of a group of fruit crops, small fruits, nuts, subtropical and grapes as to their suitability for the cultivation in Ukraine 
(PSP). National and veterinary and phytosanitary agency of Ukraine; Ukrainian institute of cultivar expertise. Vinnicia: Nilan. 84 p. (in Ukrainian).

Kosenko I. S., Opalko A. I., Balabak O. A., Opalko O. A. (2017 a). The hazelnut (Corylus domestica Kos. et Opal.) breeding program in National dendrological park «Sofiyivka» of NAS of Ukraine. Factors in Experimental Evolution of Organisms. Vol. 21. P. 154-159. (in Ukrainian).

Kosenko I. S., Opalko A. I., Balabak O. A., Opalko O. A., Balabak A. V. (2017 b). Hazelnut breeding in the National Dendrological Park "Sofiyivka" of the NAS of Ukraine. Plant varieties studying and protection. Vol. 13, № 3. P. 245-251.

Kosenko I. S. (2015) Genetic Resources of the Genus Corylus L. in the National Dendrological Park "Sofiyivka" of NAS of Ukraine. Ecological Consequences of Increasing Crop Productivity: Plant Breeding and Biotic Diversity [Eds. Anatoly I. Opalko et al.]. Toronto; New Jersey: Apple Academic Press. Ch. 16. P. 155-166.

Kosenko I. S., Opalko A. I. \& Opalko O.A. (2008) Hazelnut: Applied Genetics, Breeding, the Methods of Propagation and Production. [Ed.: Ivan Sem. Kosenko]. Kyiv: Naukova Dumka; 256 p. (in Ukrainian).

Kosenko, I. S.; Opalko, A. I. \& Shulga, S. M. (2015). Breeding material for developing new hazelnuts cultivars (Corylus domestica Kos. et Opal.) with the increased content of essence phospholipids in the nuts. Plant introduction, preservation and enriching of bio-diversity in Botanical gardens: proceedings of the international scientific conference devoted the 80th anniversary of the M. M. Gryshko National Botanic Garden of NAS of Ukraine (Kyiv, M. M. Gryshko National Botanic Garden of NAS of Ukraine, 15-17 September, 2015). Kyiv: Phytosociocenter. P. 127-129. (in Ukrainian).

Kosenko, I. S.; Opalko, A. I., Balabak, O. A. \& Shulga, S. M. (2016). Corylus spp. genetic resources use in hazelnuts Corylus domestica Kos. et Opal. improvement. Autochthonous and alien plants. Vol. 12. P. 120-136. (in Ukrainian).

Kulbida, M. I., Ielistratova, L. O. \& Barabash, M. B. (2013). Current climate conditions in Ukraine. Protection and Ecological Security: A Collection of Scientific Papers. Kharkiv: Rider. Vol. 35. P. 118-130. (in Ukrainian).

Molnar, T. J. (2011) Corylus. Wild crop relatives: genomic and breeding resources. Forest trees. [Ed.: Chittaranjan Kole]. Berlin; Heidelberg: Springer, 2011. Ch. 2. P. 15-48.

Satina G. M., Oleshchenko F. G., Koshlakova N. M., Kosenko I. S., Opalko A. I., Balabak O.A. ... \& Satina L.F. (2011). Naukovi osnovi ta skladovi Galuzevoï programi rozvitku gorikhivnictva v Ukraïni. Kï̈v: Logos. 100 s. (in Ukrainian).

Sedov, E. N. \& Ogoltsova T.P. (1999). Program and methodology for sort study of fruit, berry and nut-bearing crops. Orel: Izd-vo VNIISPK. 606 p. (in Russian).

Sukhorukikh Yu. I., Biganova S. G. \& Pchikhachev E.K. (2018). Volume of sampling at estimation of quantitative indicators of filbert fruit quality. New technologies. Vol. 2. P. 143-150. (in Russian). 